\title{
A Review and Economic Analysis of Different Emission Reduction Techniques for Marine Diesel Engines
}

\author{
Mohamad Issa $^{1 *}$, Hussein Ibrahim ${ }^{2}$, Adrian Ilinca ${ }^{3}$, M. Yasser Hayyani ${ }^{3}$ \\ ${ }^{1}$ Department of Applied Sciences, Institut Maritime du Québec, Rimouski, Canada \\ ${ }^{2}$ Department of Research and Development, Institut Technologique de Maintenance Industrielle, Sept-Îles, Canada \\ ${ }^{3}$ Department of Mathematics, Informatics and Engineering, Université du Québec à Rimouski, Rimouski, Canada \\ Email: *missa@imq.qc.ca
}

How to cite this paper: Issa, M., Ibrahim, H., Ilinca, A. and Hayyani, M.Y. (2019) A Review and Economic Analysis of Different Emission Reduction Techniques for Marine Diesel Engines. Open Journal of Marine Science, 9, 148-171.

https://doi.org/10.4236/ojms.2019.93012

Received: June 22, 2019

Accepted: July 27, 2019

Published: July 30, 2019

Copyright $\odot 2019$ by author(s) and Scientific Research Publishing Inc. This work is licensed under the Creative Commons Attribution International License (CC BY 4.0).

http://creativecommons.org/licenses/by/4.0/ cc) (i) Open Access

\begin{abstract}
The maritime industry is currently facing the challenges of adopting new technologies and operational practices with stricter international, national and local rules in order to reduce exhaust gas emissions from ships. The most objective of regulations introduced and presented by the Worldwide Sea Organization such as International Maritime Organization (IMO) and the US Environmental Protection Agency (EPA) is to lessen the commitment shipping makes to worldwide and local discharges. This paper analyzes emissions from marine engines and the process of waste exhaust gas formation and provides a summary of the emission reduction technologies to satisfy MARPOL $\mathrm{NO}_{\mathrm{x}}$ tier III and EPA tier IV rules. The results showed the possibility of achieving a valuable emission reduction percentage if future diesel engines are equipped with pre-treatment, internal-treatment and/or post-treatment techniques. Economics impact for medium and low speed for category 3 marine diesel engines is also presented.
\end{abstract}

\section{Keywords}

Air Pollution, GHG, IMO Requirements, Tier III, Tier IV, Scrubber, SCR, Exhaust Gas Emissions

\section{Introduction}

In recent years, marine diesel engine manufacturers have had to address the challenge of tightening controls on baneful exhaust gas emissions obligatory by regional, national and international authorities responding to concern over atmospheric pollution and its impact on human health and climate amendment. 
International Maritime Organization (IMO) regulations concerning gas oxides had planned to accomplish emissions reduction emitted by diesel engines (DE) through three tiers [1].

Tier I for vessels launched after first of January 2000, tier II, for vessels launched after first of January 2011 with 15\% exhaust gas emissions reduction of tier I, while tier III for vessels launched after first of January 2016 with 85\% exhaust gas emissions reduction of tier I [2]. The current allowable $\mathrm{NO}_{\mathrm{x}}$ discharge level as per IMO control relies upon the speed class of the engine and ranges [3]. Besides, the regulations for the prevention of Air pollution from vessels (Annex VI) additionally forced a 1.5 percent Sulphur limit on marine power engines in Emission Control Areas (ECAs) viable since 2006, this limit decreased to $1.0 \%$ Sulphur compelling from first of July 2010 and was additionally diminished to $0.1 \%$ Sulphur starting on January 2015 [4]. Furthermore, in May 2004, the US Environmental Protection Agency (EPA) signed the final rule introducing Tier IV emission standards, which are phased-in over the period 2008-2015. The tier IV rules necessitate that outflows of particulate matter (PM) and $\mathrm{NO}_{\mathrm{x}}$ be additionally decreased by $99 \%$ [5]. Figure 1 shows the emissions regulations

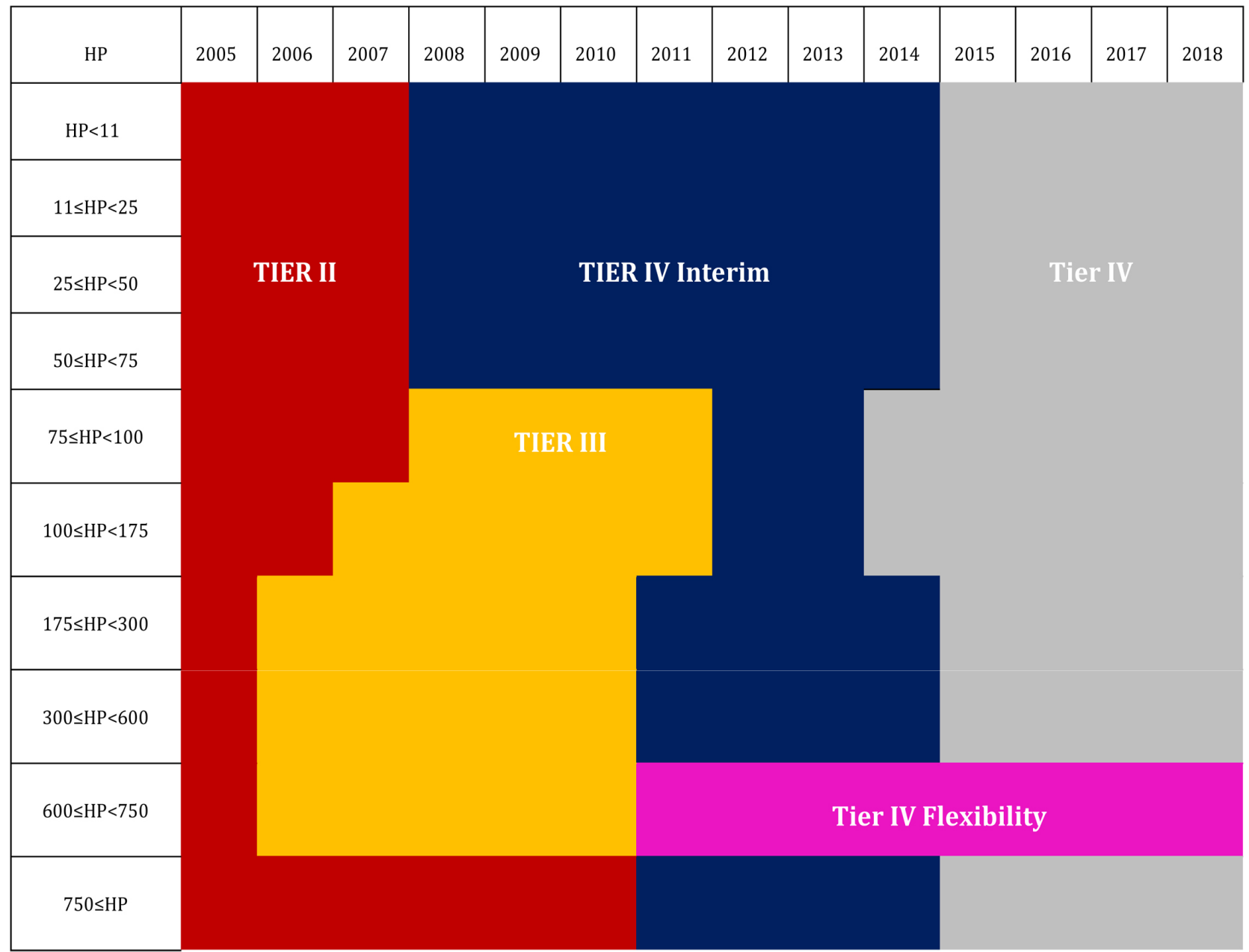

Figure 1. Implementation of Tiers II-IV for nonroad diesel engines over the last decade. 
implemented over the last two decades on different diesel engines size and culminated in 2015 with Tier IV final.

It should be noted here that Tier 4 Flexibility rules allow pre-approved equipment manufacturers to use the previous-Tier engines in lieu of Tier 4 Interim or Tier 4 final engines for up to a seven-year phase-in period in order to provide equipment manufacturers with some control over their transition to the new emission standards.

However, emergency standby power (ESP) has been exempted from EPA tier IV because tier III already decreases over 85 percent exhaust gas emissions that occurred through in-engine structure upgrades and because of ESP's runs for a short period of time during a year. For application other than ESP, diesel power generators are phased-in two steps, starting with tier IV interim in 2011 and tier IV final rules by 2015 (Figure 2). Moreover, in order to achieve the level of emission control required to meet tier IV interim and tier IV final rules, some form of exhaust after-treatment will be required.

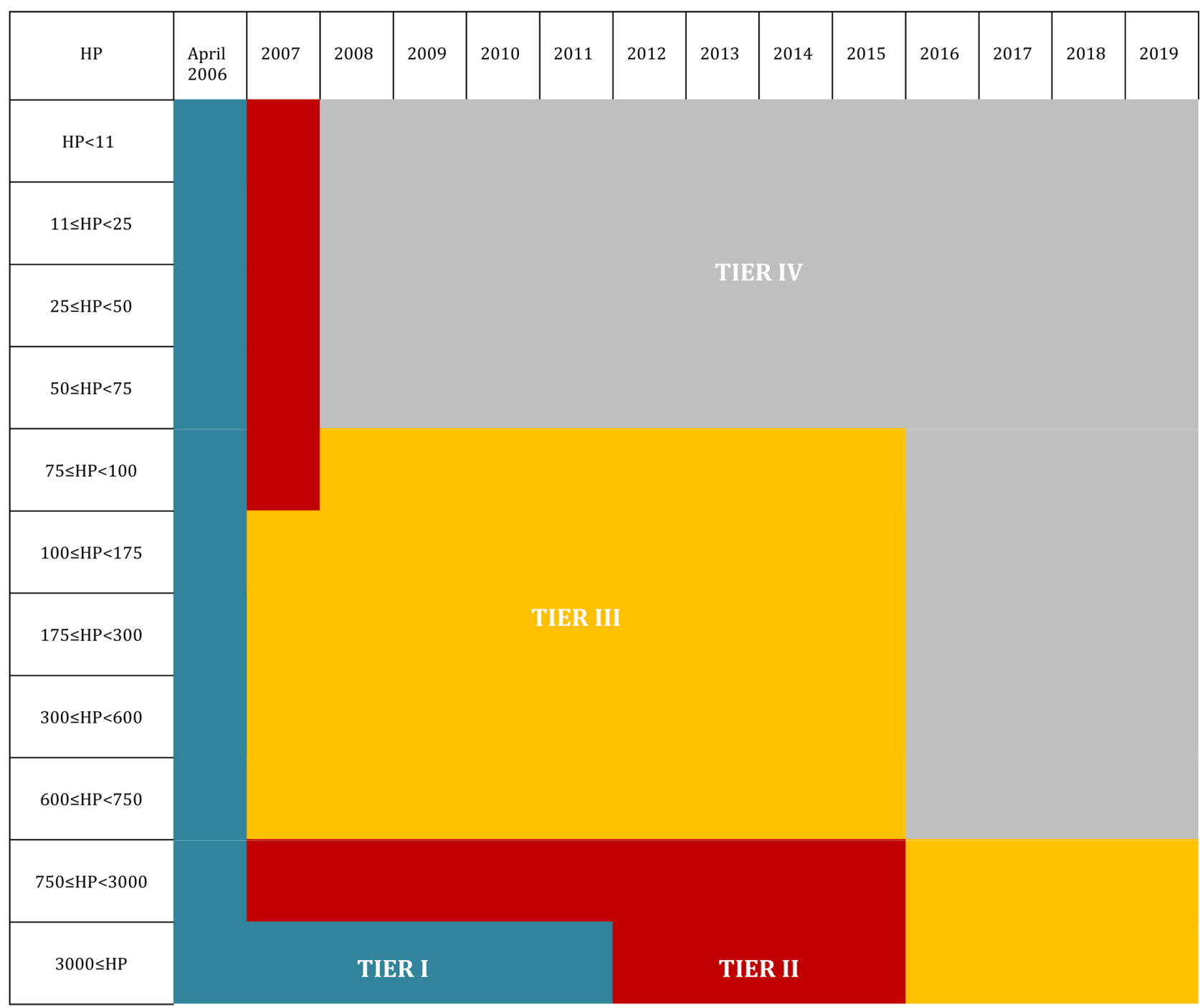

Figure 2. Implementation of Tiers I-IV for diesel power generators over the last years. 
The structure of the present paper is as follows. Section 2 presents the main pollutants from marine diesel engines, particularly nitrogen oxides $\left(\mathrm{NO}_{\mathrm{x}}\right)$, Sulphur Oxides $\left(\mathrm{SO}_{\mathrm{x}}\right)$ and smoke in general. In Section 3, $\mathrm{NO}_{\mathrm{x}}$ and $\mathrm{SO}_{\mathrm{x}}$ emissions control technologies such as internal-treatment and add-on technologies are presented. In Section 4 we evaluate the economic impact of the selected technology for category 3 marine DEs in order to determine the estimated cost of compliance with potential future emission regulations. Finally, Section 5 provides a conclusion of our study.

\section{Exhaust Gas Emissions from Marine Diesel Propulsion Engines}

Marine diesel propulsion engines are characterized by their speed (Low, Medium or High) and stroke numbers. According to Kristensen H.O. [6], the following engines are used for propulsion: 1) Low speed two stroke DE (50 - 300 RPM), 2) Medium speed four stroke DE (300 - $1000 \mathrm{rpm}$ ), 3) High speed four stroke DE (1000 - $3000 \mathrm{rpm}$ ), and 4) Gas turbine (very high rpm > $5000 \mathrm{rpm}$ ). These DEs run with air excess. Diesel is injected into the cylinder chamber at high pressures, which is compressed by moving cylinders. This compression increments sufficiently the air temperature in the cylinder chamber allowing the fuel to ignite. However, combustion creations have a significant percentage of nitrogen and oxygen due to the air reaction (1) [7].

$$
\mathrm{C}_{\mathrm{a}} \mathrm{H}_{\mathrm{b}}+\left(\mathrm{O}_{2}+3.75 \mathrm{~N}_{2}\right) \rightarrow \mathrm{CO}_{2}+\mathrm{H}_{2} \mathrm{O}+\mathrm{N}_{2}+\mathrm{O}_{2}+\text { Other }
$$

Additional exhaust gas emissions from marine diesel engines largely comprise oxides of Sulphur, carbon dioxide and water vapour, with a few quantities of carbon monoxide, partially reacted and non-combusted PM and hydrocarbons (HC). Classic exhaust gas emissions from a low speed DE are shown in Figure 3, while Figure 4 illustrates the typical content of the exhaust gas emissions from a

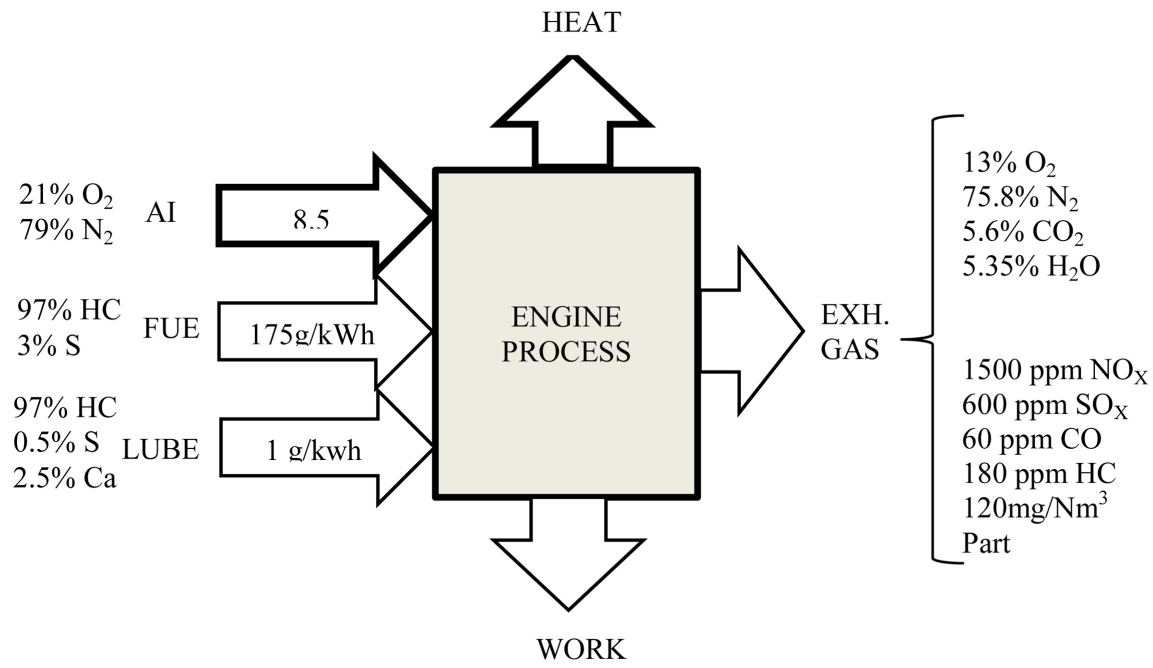

Figure 3. Typical exhaust gas emissions from a $41 \mathrm{MW}$ low speed DE [9]. 


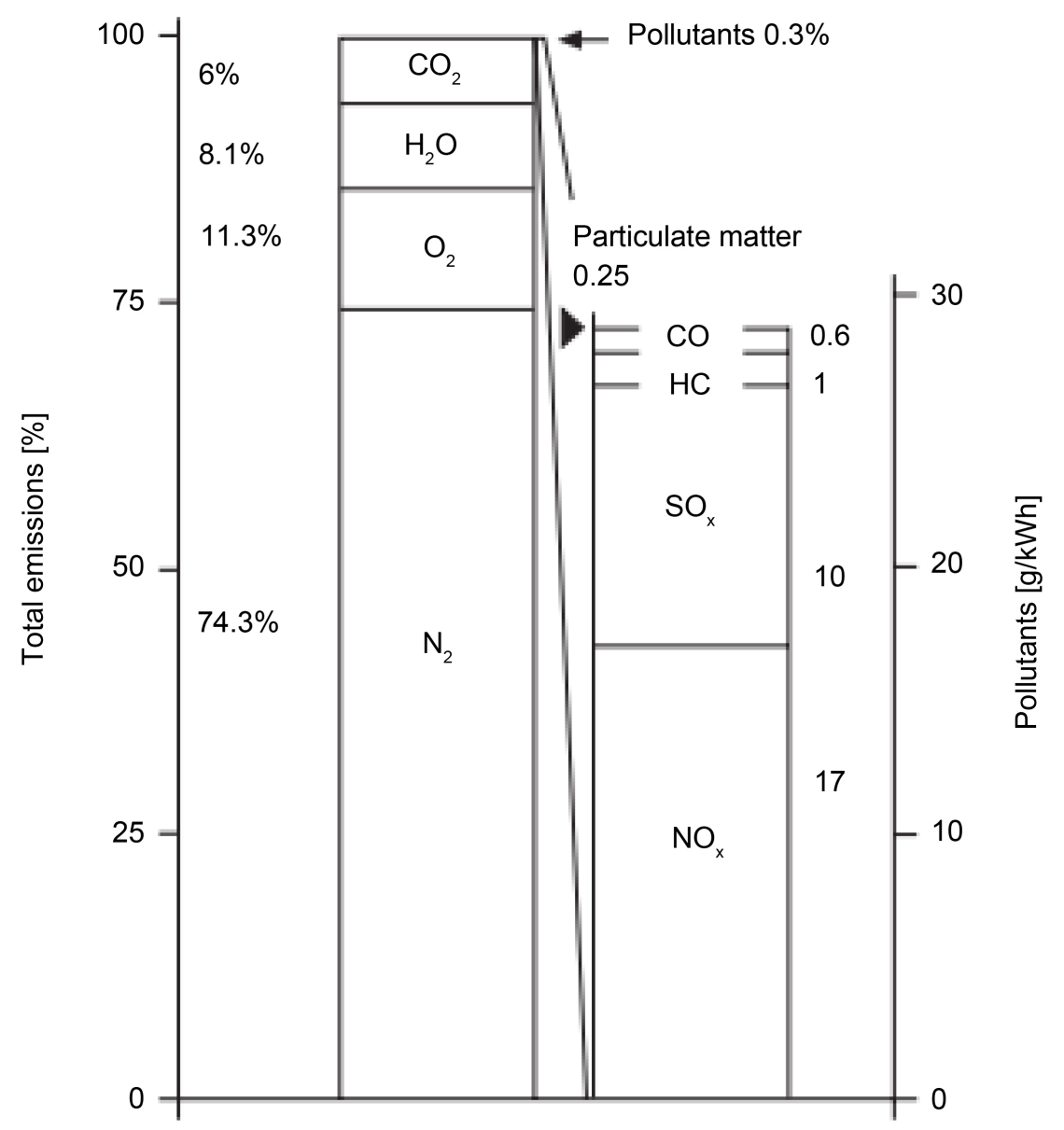

Figure 4. Typical exhaust gas composition of a medium speed four strokes $18 \mathrm{MW} \mathrm{DE}$ burning heavy fuel oil (HFO) with $3 \%$ Sulphur content [9].

medium speed DE burning heavy fuel oil with a mean of 3 percent Sulphur content [8].

According to Figure 4, the principle emissions are nitrogen $\left(\mathrm{N}_{2}\right)$, Oxygen $\left(\mathrm{O}_{2}\right)$, water $\left(\mathrm{H}_{2} \mathrm{O}\right)$ and carbon dioxide $\left(\mathrm{CO}_{2}\right)$. Among these gases, carbon dioxide is considered as potential source for greenhouse gas (GHG) development. Different studies have evaluated that 3 to 4 percent of universal $\mathrm{CO}_{2}$ emissions are attributable to marine vessels [10]. A 10 percent reduction in cruise speed is an effective operational methodology that offers a significant reduction in $\mathrm{CO}_{2}$ and fuel consumption up to 20 percent over the same distance [11]. Below are described the main pollutants emitted by a marine diesel engine which contribute to air pollution and human health risks.

\subsection{Nitrogen $\left(\mathrm{N}_{2}\right)$ and Oxygen $\left(\mathrm{O}_{2}\right)$}

Nitrogen and Oxygen are not poisonous. $\mathrm{N}_{2}$ and $\mathrm{O}_{2}$ are the main components of both air intake and exhaust emissions from engines. Nitrogen which forms 78 percent by volume of intake air, mostly do not react during the combustion operation, despite a very small portion will react chemically creating diverse oxides 
of nitrogen $\left(\mathrm{NO}_{\mathrm{x}}\right) . \mathrm{O}_{2}$ which forms 21 percent of the intake air, will be moderately transformed by the combustion operation, therefore, the free $\mathrm{O}_{2}$ of the exhaust will depend on the excess air ratio along which engine is operated [12].

\subsection{Carbon Dioxide $\left(\mathrm{CO}_{2}\right)$ and Water Vapor $\left(\mathrm{H}_{2} \mathrm{O}\right)$}

The production of both carbon dioxide and water vapor depends on the quantity of fuel burned and the fundamental composition of the fuel burned. $\mathrm{CO}_{2}$ and $\mathrm{H}_{2} \mathrm{O}$ vapor will be created in all combustion forms such as completed or nearly completed. Carbon dioxide is considered as a GHG that absorbs and transmits radiation inside the thermal infrared spectrum length [13].

\subsection{Micro Pollutants}

In the context of DE emissions, micro pollutants will enclose organic and heavy metals micro pollutants. Organic micro pollutants generally consist of dioxins, furans and polyaromatic hydrocarbons (PAH). However, $\mathrm{PAH}$ is well identified and known as a carcinogen for humans and is well documented. Furthermore, polychlorinated dibenzofurans (PCDF) has been reported as highly toxic and has been identified in the engine exhaust system. Heavy metals such as copper, mercury, cadmium, chromium, nickel and zinc are highly toxic and can cause serious damage by reducing the diversity of aquatic ecosystems, over fish kills to cancer in humans.

\subsection{Sulphur Oxides (SOX)}

Sulphur oxides are related precisely from the Sulphur content of the used fuels. Oxidation of the Sulphur inside the combustion chamber allows the formation of the Sulphur dioxide $\left(\mathrm{SO}_{2}\right)$ and a smaller proportion of the Sulphur trioxide $\left(\mathrm{SO}_{3}\right) . \mathrm{SO}_{\mathrm{x}}$ have bad odor and are a bigger source of acid rain. $\mathrm{SO}_{\mathrm{x}}$ represent around $60 \%$ of universal transport $\mathrm{SO}_{\mathrm{x}}$ emissions and symbolize dangerous source to human health. New strict regulations to reduce $\mathrm{SO}_{\mathrm{x}}$ emissions are adopted recently such as the regulation 14 of the MARPOL Annex VI which imposes Sulphur limitations to the fuel used for marine applications.

\subsection{Oxides of Nitrogen ( $\mathrm{NO}_{\mathrm{x}}$ )}

The development of nitrogen oxides is caused by the oxidation of molecular nitrogen in the combustion air or by the oxidation of organic nitrogen in the fuel. Depending on the fuel used, important portion of the total nitrogen oxides emissions, are related for engines using HFO. It is known that the evolution of nitrogen oxides growths with the combustion temperature. As a result, slow speed marine DE produce high level of $\mathrm{NO}_{\mathrm{x}}$ compared to a medium or high-speed marine DE. This can be explained by the fact that slow speed marine $\mathrm{DE}$ requires a longer time period for his combustion process so there is greater time ready for use for $\mathrm{NO}_{\mathrm{x}}$ development. Nitrogen oxides aims to acid rain and its oxidation in the atmosphere leads to the creation of fine nitrate particles, which can pose a sig- 
nificant danger to human health.

\section{3. $\mathrm{NO}_{\mathrm{x}}$ and $\mathrm{SO}_{\mathrm{x}}$ Emissions Control Technologies}

Emission control technologies for oxides of nitrogen can be divided through two categories: internal modification to the $\mathrm{DE}$ and add-on technologies. Add-on technologies include pre-treatment and post-treatment techniques.

Internal modifications to the DEs are commonly desirable to exhaust treatment. However, external treatment brings several disadvantages such as costs, zone restraints and extended fuel consumption which has direct environmental impact, particularly on GHG as well as financial. While emission control technologies for $\mathrm{NO}_{\mathrm{x}}$ can be achieved by internal modifications to the $\mathrm{DE}$ or by add-on technologies, there is no consequence on Sulphur oxides emissions by bringing measures within the DE. Currently, there is one way to minimize the $\mathrm{SO}_{\mathrm{x}}$ emissions by applying after-treatment technology or using low Sulphur content fuel such as liquified natural gas, biofuels and light marine fuel oil (LMFO). Figure 5 illustrates the $\mathrm{DE}-\mathrm{NO}_{\mathrm{x}}$ and $\mathrm{SO}_{\mathrm{x}}$ reduction emissions based on pre-treatment, internal treatment and post treatment technologies.

\subsection{Marine Diesel Engine Emissions Reduction Solutions Using Pre-Treatment Technologies}

Pre-treatment is the easiest and fastest way to comply with the emissions regulation recently adopted by the IMO. However, low-Sulphur substitute fuel such as methanol and liquified natural gas (LNG) face several challenges in terms of adaptability on board. In terms of engineering, they require dual-fuel engines and additional special fuel storage tanks.

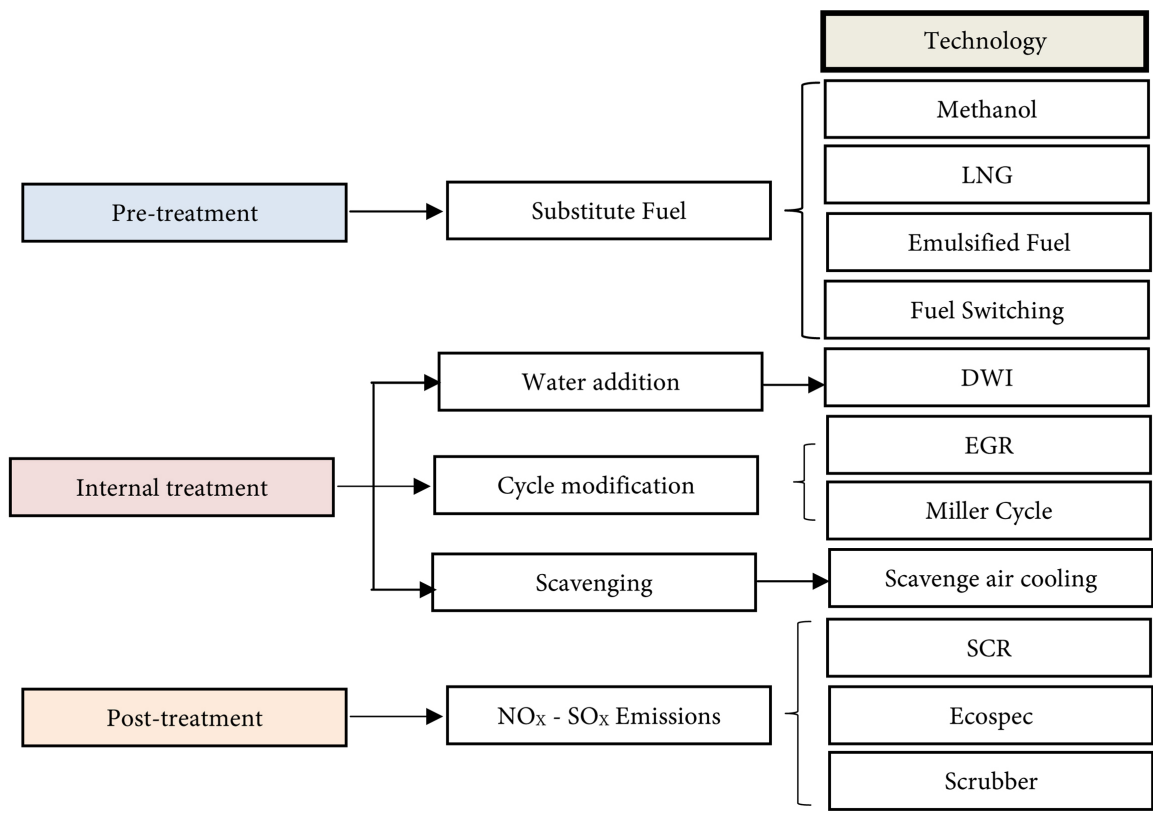

Figure 5. Methods of reducing $\mathrm{SO}_{\mathrm{x}}$ and $\mathrm{NO}_{\mathrm{x}}$ emissions from marine diesel engines using pre-treatment, internal-treatment and post treatment solutions [14]. 
Methanol has the advantage to reduce $\mathrm{SO}_{\mathrm{x}}, \mathrm{NO}_{\mathrm{x}}$ and $\mathrm{PM}$ emissions by an amount of about $99 \%, 60 \%$ and $95 \%$ compared to heavy fuel oil (HFO) for marine use, while $\mathrm{LNG}$ has the advantage to reduce $\mathrm{SO}_{x}, \mathrm{NO}_{\mathrm{x}}, \mathrm{CO}_{2}$ and $\mathrm{PM}$ by $98 \%$, $86 \%, 11 \%$ and $96 \%$ respectively [15], Figure 6 . However, methanol raises the possibility of corrosion and must be faced with adequate upgrading of fuel storage tanks. On the other hand, LNG retains about $85 \%$ of the energy stocked per unit volume compared to traditional oil fuel. One of the most vital challenges of the use of LNG as a marine fuel, is the higher size of his tanks (3 - 4 times greater) than the marine diesel oil tanks [16]. This further increases the costs of installations for a retrofit. Recently, a study conducted and published by DNV-GL [17], confirms that LNG-fueled fleet will increase very-quickly over the next years, especially in zones with existing bunkering abilities. Moreover, a previous study assessed by Wärtsilä in order to evaluate the advantages of changing from HFO fueled engine equipped with a Sea scrubber to LNG fueled engine [18] has shown additional savings from the annual machinery cost (maintenance, oil lubricating, scrubber and SCR with annual capital) by an amount of $500 \$ / \mathrm{kW}$. Furthermore, the expansion in navigation time in emission control areas (ECAs) where high quality fuel is required will add more economic interests to LNG than HFO-powered engines where stricter emission regulations are approved and implemented. Figure 7 shows price comparison between HFO and LNG for three engine grades conforming to the current fuel price (January 2019), is about 15.3\$ US/MMBtu for HFO and 11.6\$ US/MMBtu for LNG.

Emulsified fuel relies on decreasing the temperature in the combustion chamber by adding water to the fuel. Emulsified fuel offers the advantage for a better atomization and a better distribution of the fuel inside the combustion chamber resulting in a complete combustion. Emulsified fuel has the advantage to reduce the nitrogen oxides emissions and PM. However, it also motives corrosion of engine components and the short common of oil-water separation

\section{Typical Emissions from LNG Compared to HFO \\ aNG $\square \mathrm{HFO}$}

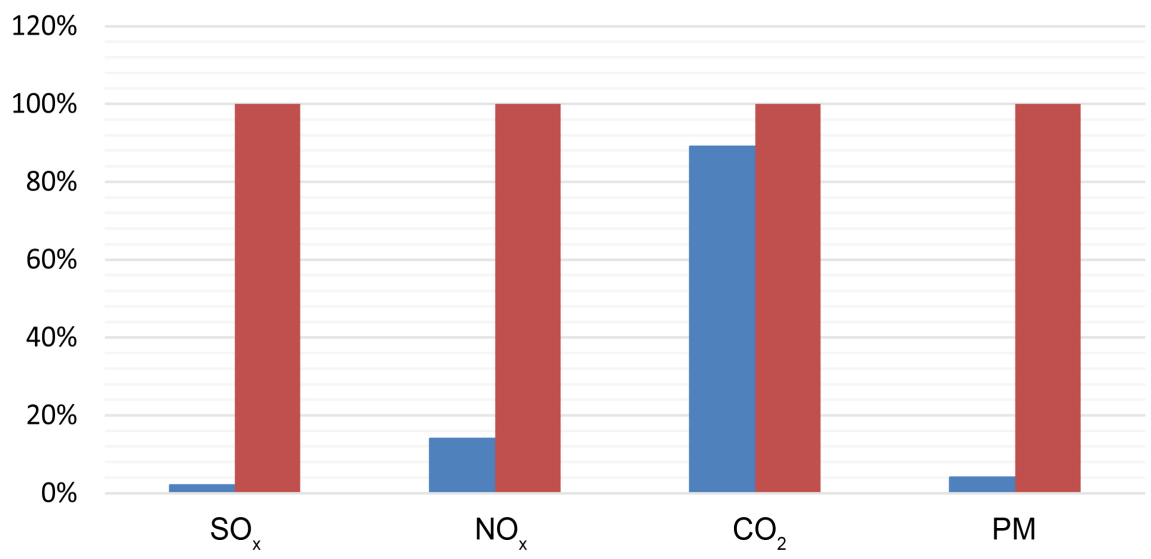

Figure 6. Relative gas emissions for LNG and HFO 


\section{Cost comparison based on $8000 \mathrm{hrs} /$ year}

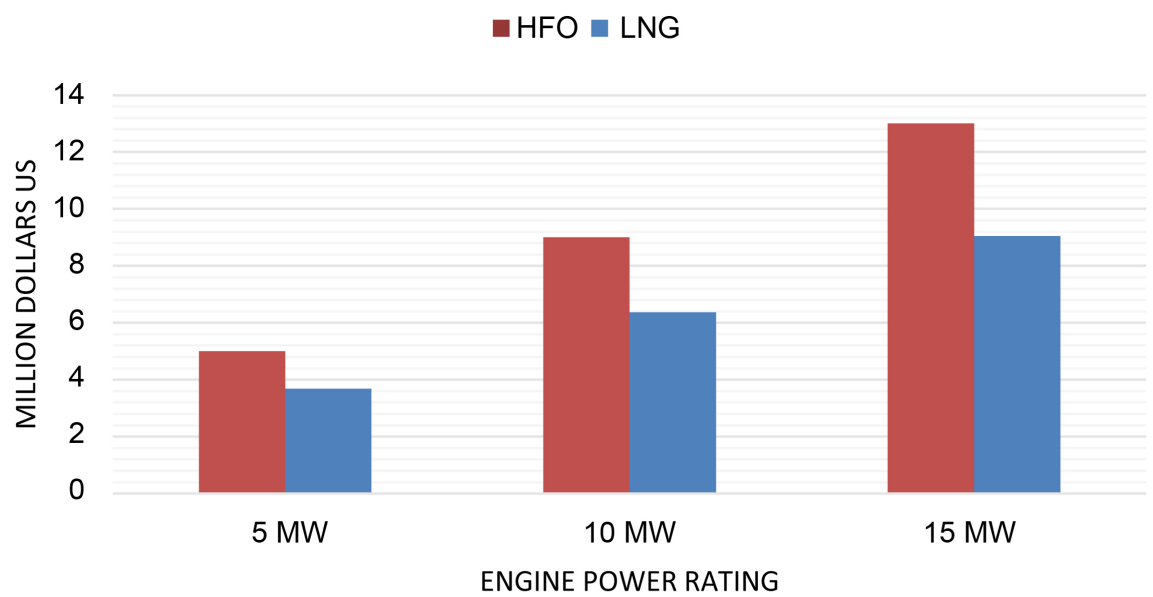

Figure 7. Price comparison between LNG and HFO for different marine engine grades.

phenomenon [19]. To conclude this section, many DE manufacturers such as Wärtsila and MAN B\&W have developed DEs that can be run on natural gas, marine diesel oil (MDO) or heavy fuel oil (HFO). This is known as fuel switching technology or dual-fuel technology [20]. The dual-fuel technology provides shipowners and operators with outstanding benefits. In gas mode, without any secondary exhaust gas purification systems, the engine is already compliant with IMO Tier III regulations [21]. Furthermore, dual-fuel technology offers reduced emissions of $\mathrm{SO}_{\mathrm{x}}$ and $\mathrm{CO}_{2}$ as well as smokeless operation in gas mode. On the other hand, dual-fuel technology allows the operator to select the type of fuel to be used based on the market price variation. However, there are several disadvantages [22]. First, a spark ignited gas engine's power output is lower than that of a diesel engine of similar size. This translates during initial installation into a higher capital investment. There are also high maintenance costs for the spark ignition system. While many producers continue to provide in the development of longer-life spark plugs, there is still concern about their operating life. Furthermore, spark ignited engines run hotter than their diesel complements, resulting in significantly higher valve seat wear rates. Table 1 summarizes the benefits and limitations between alternative fuels for marine use considered as pre-treatment solutions.

\subsection{Marine Diesel Engine Emissions Reduction Solutions Using Internal-Treatment Technologies}

Internal treatment consists of a direct modification in the diesel engine. This is done by the DE manufacturers and may require modifications in the injectors design such as the use of direct water injection (DWI) and/or engine cycle such as the use of Miller cycle and/or combustion chamber such as the use of scavenge air temperature. All these technologies have a positive impact on the reduction of $\mathrm{NO}_{\mathrm{x}}$ and $\mathrm{PM}$ and can further achieve the standards set out in Annex VI of the MARPOL convention. 
Table 1. Benefits and limitations between the alternative fuels for marine application.

\begin{tabular}{|c|c|c|c|}
\hline Technology & Benefits & Limitations & References \\
\hline $\begin{array}{c}\text { Emulsified } \\
\text { Fuel }\end{array}$ & $\begin{array}{l}\text { Allows significant } \mathrm{NO}_{\mathrm{x}} \\
\text { reduction by an amount } \\
\text { of } 80 \%\end{array}$ & $\begin{array}{l}\text { - Increase the fuel } \\
\text { consumption by } 3 \% \text { to } \\
\text { achieve the same output } \\
\text { - Corrosive }\end{array}$ & [19] \\
\hline Methanol & $\begin{array}{l}\text { - } \text { Renewable resource } \\
\text { - } \\
\text { - } \\
\text { Allodegradable } \mathrm{NO}_{\mathrm{x}} \text { reduction by } \\
\text { an amount of } 60 \% \text { and fuel } \\
\text { consumption by } 2 \% \text { - } 3 \%\end{array}$ & $\begin{array}{l}\text { - } \text { Corrosive } \\
\text { - Toxic } \\
\text { - } \text { Burns with } \\
\text { - } \text { non-luminous flame } \\
\text { - } \text { Miscible with water }\end{array}$ & $\begin{array}{l}{[15][16]} \\
{[17][18]}\end{array}$ \\
\hline LNG & $\begin{array}{l}\text { Has environmental } \\
\text { benefits through an } \\
\text { average reduction of } \mathrm{SO}_{\mathrm{x}} \text {, } \\
\mathrm{NO}_{\mathrm{x}} \text {, and } \mathrm{PM} \\
\text { - Lower operating cost }\end{array}$ & $\begin{array}{l}\text { - Highly flammable } \\
\text { - Requires huge } \\
\text { investments for storage } \\
\text { and installation } \\
\text { - High } \mathrm{CO}_{2} \text { emissions }\end{array}$ & $\begin{array}{l}{[15][16]} \\
{[17][18]}\end{array}$ \\
\hline $\begin{array}{c}\text { Fuel } \\
\text { Switching }\end{array}$ & $\begin{array}{l}\text { Allows much lower } \\
\text { emissions of oxides of } \\
\text { nitrogen and PM } \\
\text { - Can be designed to operate } \\
\text { interchangeably on natural } \\
\text { gas with diesel pilot or on } \\
100 \% \text { diesel fuel }\end{array}$ & $\begin{array}{l}\text { - High capital cost in } \\
\text { general } \\
\text { - Requires high } \\
\text { maintenance for the } \\
\text { spark ignition system }\end{array}$ & [20] [22] \\
\hline
\end{tabular}

DWI technology uses an injector composed of two parts, one to spray water and the other to inject fuel oil. During the fuel injection phase, the water-fuel density $0.4-0.7$ high pressure water is injected into the combustion chamber and the mixture of water and combustion gas is completed, allowing a reduction of combustion temperatures and $\mathrm{NO}_{\mathrm{x}}$ emissions by up to 60 percent [23] Another advantage of using this technology appears in the fact that it does not require an extra space or additional cost and can be integrated for a medium speed marine diesel engine. However, this technology can bring to lightly more fuel consumption rate by $2 \%$ approximately. On the other hand, Miller cycle was initially proposed by Ralph Miller in 1947 and consists to use the Early Intake Valve Closing (EIVC) to achieve internal cooling before compression in order to reduce the compression cycle work [24]. The Miller cycle is considered as a cold cycle and allows a lower $\mathrm{NO}_{\mathrm{x}}$ emission up to $40 \%-60 \%$ and increase the efficiency of the engine [25]. Furthermore, Miller cycle can be used on four stroke marine diesel engine to complete low scavenge air temperature [26]. By reducing the scavenge air temperature, combustion temperatures and $\mathrm{NO}_{\mathrm{x}}$ are also reduced. According to Holtbecker, M. [27], for each $3^{\circ} \mathrm{C}$ reduction, nitrogen oxide decreases approximatively by 1 percent. Moreover, internal engine technology such as Exhaust Gas Recirculation (EGR) results in combustion temperature reduction and small $\mathrm{NO}_{\mathrm{x}}$ composition. It is considered as the principal technology to reduce $\mathrm{NO}_{\mathrm{x}}$ from DE. Figure 8 illustrates the schematic diagram of EGR technology [28]. The resulting combination of exhaust gas with the fresh air 


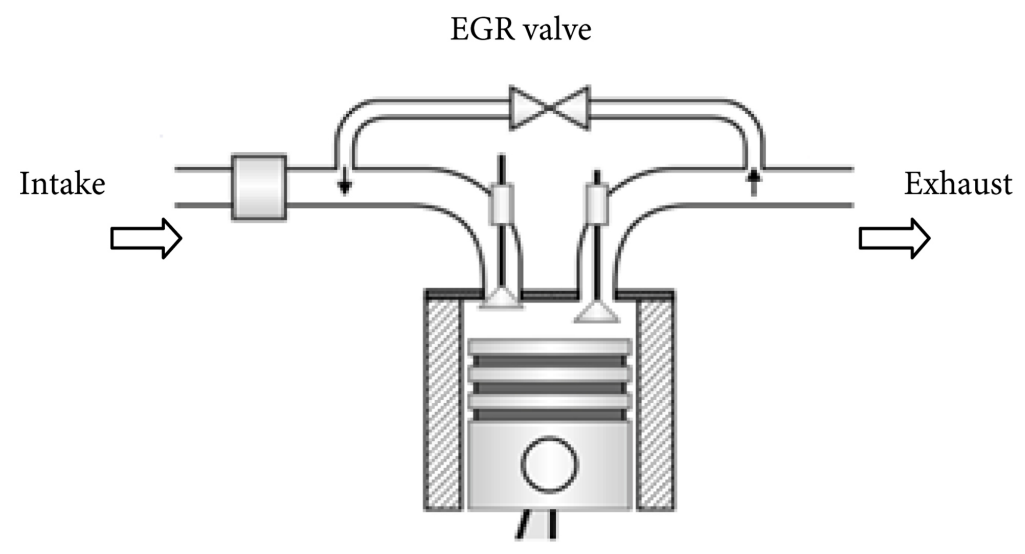

Figure 8. Schematic diagram of EGR [29].

has a low volume calorific value, which reduces the combustion chamber temperatures, and allows $\mathrm{NO}_{\mathrm{x}}$ less formation by 40 percent and more. However, the production of PM is increased due to the reduction of oxygen in the combustion chamber when applying EGR [29]. The deliberate reduction in the cylinder's oxygen available will reduce the engine's peak power. For this reason, when full power is required, the EGR is usually shut down, so in this situation, the EGR approach to controlling $\mathrm{NO}_{\mathrm{x}}$ fails. Table 2 summarizes the benefits and limitations of the selected Internal-treatment technologies.

\subsection{Marine Diesel Engine Emissions Reduction Solutions Using Post-Treatment Technologies}

Today, post-treatment technologies are considered the most suitable solutions for maritime industry to reduce $\mathrm{NO}_{\mathrm{x}}$ and $\mathrm{SO}_{\mathrm{x}}$ emissions from the exhaust gas engine. They can be integrated into service ships that were launched before the adoption of tier II or tier III and use heavy fuel oil (HFO) with 3\% Sulphur content. In terms of efficiency, Seawater scrubbers such as open-loop, closed-loop and Ecospec scrubbers offers up to $99 \%$ and $60 \%$ abatement of $\mathrm{SO}_{\mathrm{x}}$ and $\mathrm{NO}_{\mathrm{x}}$ [30] [31], allowing shipowners to continue to use the HFO which is cheaper to buy than light fuel oil (LFO) with $0.1 \%$ Sulphur content. The open loop scrubber is the easiest system, where water is supplied from the sea, pumped, filtered and sprayed into the scrubber using nozzles that diffuse water into droplets. However, open loop scrubber is only profitable if the water is alkaline. This can be accomplished by adding an alkali chemistry or by using seawater with a natural alkalinity extracted from the bicarbonate ion $\left(\mathrm{HCO}_{3}^{-}\right)$existing in the seawater [31] [32]. The water is released back into the sea after particular matters are eliminated. Operation of the open loop scrubber system in fresh water can restrict scrubbing of $\mathrm{SO}_{\mathrm{x}}$ due to the weak alkalinity of the water. For this, it is therefore more interesting to use a closed-loop scrubber, where, fresh water treated with an alkaline chemical like caustic soda is employed for neutralization. Fresh water scrubbers are used when high efficiency cleaning is required or when the varying alkalinity associated with seawater prevents the use of marine scrubbers. 
Table 2. Benefits and limitations of the selected internal-treatment solutions.

\begin{tabular}{|c|c|c|c|}
\hline Technology & Benefits & Limitations & References \\
\hline DWI & $\begin{array}{l}\text { - Potential reduction of } \\
\mathrm{NO}_{\mathrm{x}} \text { by an amount of } \\
60 \% \\
\text { - Can be applied for } \\
\text { Medium Speed Marine } \\
\text { Diesel Engine }\end{array}$ & $\begin{array}{l}\text { - Increase the fuel } \\
\text { consumption by } 2 \%-3 \%\end{array}$ & [23] \\
\hline Miller Cycle & $\begin{array}{l}\text { - Increase efficiency } \\
\text { of the engine } \\
\text { - Potential reduction of } \\
\mathrm{NO}_{\mathrm{x}} \text { by an amount of } \\
40 \%-60 \%\end{array}$ & $\begin{array}{l}\text { - Requires high } \\
\text { maintenance } \\
\text { - High cost }\end{array}$ & $\begin{array}{c}{[24][25]} \\
\quad[26]\end{array}$ \\
\hline $\begin{array}{l}\text { Scavenge Air } \\
\text { Temperature }\end{array}$ & $\begin{array}{l}\text { Potential reduction of } \\
\mathrm{NO}_{\mathrm{x}} \text { by an amount of } \\
60 \% \\
\text { - Reduce number and } \\
\text { size of exhausts ports }\end{array}$ & $\begin{array}{l}\text { - Cylinder head complex } \\
\text { - Additional maintenance } \\
\text { is required }\end{array}$ & [27] \\
\hline $\begin{array}{l}\text { Exhaust Gas } \\
\text { Recirculation } \\
\text { (EGR) }\end{array}$ & $\begin{array}{l}\text { - Allows } \mathrm{NO}_{\mathrm{x}} \text { emission } \\
\text { reductions by } 30 \% \\
\text { - } \quad \text { Low operating cost }\end{array}$ & $\begin{array}{l}\text { - Cannot be employed at } \\
\text { high loads because it } \\
\text { would reduce peak } \\
\text { power output } \\
\text { - Increase the production } \\
\text { of PM }\end{array}$ & [28] [29] \\
\hline
\end{tabular}

Nevertheless, closed loop fresh water scrubber systems have much smaller discharge rates than open loop sea scrubber systems by an amount approximately of 0.1 to $0.3 \mathrm{~m}^{3} / \mathrm{MWh}$ and occur a smaller volume of effluent [33]. Moreover, closed loop fresh water scrubber system can periodically be operated in zero discharge mode without discharging any overboard wash water. Despite their advantages, open loop scrubber are affected by corrosion (salt water), while closed loop scrubber requires more space to hold wastewater and hazardous chemical solutions [34] [35] [36]. Both systems require additional electric power for pumping and managing wastewater by an amount of $150 \mathrm{~kW}$. On the other hand, Ecospec Marine of Singapore proposed their $\mathrm{CSNO}_{\mathrm{x}}$ scrubber system which allows significant reductions in $\mathrm{NO}_{x}, \mathrm{SO}_{x}$ and $\mathrm{CO}_{2}$ in a single process [37]. It consists of two stages. The first stage is an open-loop wet scrubber related to a wash water handling techniques, while the second stage uses seawater conditioned by ultra-low frequency (ULF) waves resulting in alkaline seawater that allegedly absorbs the $\mathrm{SO}_{\mathrm{x}}, \mathrm{NO}_{\mathrm{x}}$ and $\mathrm{CO}_{2}$. However, maintenance and repair costs are expected to be 4 percent of the cost of the equipment each year. Supplementary engineer is pretended to spend partially half time on scrubber operations for operations. The engineer's cost will vary significantly depending on the ship's flag. Furthermore, scrubber installation is challenging for new buildings and retrofits alike. Significant considerations include:

- Weight and balance: weights depending on the scrubber rating and type will 
vary significantly. The primarily weights of concern are the scrubbers themselves and even a 20 ton wet weight could be considerable concern for ships stability.

- Systems for water handling: These systems can be important for any of the wet systems, but especially for open loop scrubber. For example, an open loop scrubber $50 \mathrm{MW}$ plant will require 4500 cubic meters of wash water an hour. This wash water would require a running capacity of about $500 \mathrm{~kW}$ and a pipe of $760 \mathrm{~mm}$ (30 inch diameter).

- Backpressure to exhaust: Most engines can tolerate $3.0 \mathrm{kPa}$ backpressure without significant power degradation or adverse effects. For each additional $3 \mathrm{kPa}$ of back pressure, exceeding the ratio will degrade performance by $1 \%$.

- Electrical power: these systems' needs can reach $2 \%$ of nominal power significantly. Additional generator must be taken into consideration.

- Arrangements for machinery and stacking: for retrofits, it will be a significant challenge to fit the scrubber into existing spaces.

Otherwise, Selective Catalytic Reduction (SCR) technology offers the largest reduction of nitrogen oxide up to 90 percent on Des [38] [39]. The functioning principle is that the waste exhaust gas is combined with ammonia $\left(\mathrm{NH}_{3}\right)$ or urea before passing over a special catalyst layer at a high temperature between $300^{\circ} \mathrm{C}$ $400^{\circ} \mathrm{C}$, reducing the $\mathrm{NO}_{\mathrm{x}}$ to $\mathrm{N}_{2}$ and water $\left(\mathrm{H}_{2} \mathrm{O}\right)(2)$ and (3).

$$
\begin{gathered}
4 \mathrm{NO}+4 \mathrm{NH}_{3}+\mathrm{O}_{2} \rightarrow 4 \mathrm{~N}_{2}+6 \mathrm{H}_{2} \mathrm{O} \\
6 \mathrm{NO}_{2}+8 \mathrm{NH}_{3} \rightarrow 7 \mathrm{~N}_{2}+12 \mathrm{H}_{2} \mathrm{O}
\end{gathered}
$$

According to Wärtsilä manufacturer, SCR is the best technology to achieve tier III compliance. Table 3 summarizes the benefits and limitations of the selected Post-treatment technologies.

\section{Economic Analysis of the Selected Technologies}

Each technology mentioned above has their advantages and disadvantages. In order to give a potential estimated cost to the selected method, a typical model of low and medium speed for category 3 marine diesel engines (MDE) were chosen among various DE manufacturer's which are characterized by their cylinder's displacement at or above 30 liters per cylinder, used for propulsion power on ocean going vessels such as container ships, oil tankers, bulk carriers and cruise ships, see Table 4. These include fuel emulsions, DWI, EGR, SCR, fuel switching (for new construction vessels) and scrubbers. With regard the fuel switching, we have considered the fact that new vessels will be built with further distillate fuel storage systems over existing vessels. Prices include an LFO separator, a three-way valve, an HFO/LFO blending unit, filters, a viscosity meter and various pumps and piping.

\subsection{Methodology for Estimating Cost}

We did not define a single model's costs to estimate the economic impact of all 
Table 3. Benefits and limitations of the selected post-treatment solutions.

\begin{tabular}{|c|c|c|c|}
\hline Technology & Benefits & Limitations & References \\
\hline SCR & $\begin{array}{l}\text { - Potential reduction of } \\
\mathrm{NO}_{\mathrm{x}} \text { by an amount of } 95 \% \\
\text { - Relatively simple } \\
\text { installation }\end{array}$ & $\begin{array}{l}\text { - } \\
\text { Expensive } \\
\text { from erosion caused } \\
\text { by flue gases } \\
\text { - } \quad \text { Requires enough space } \\
\text { that can be complex or } \\
\text { not feasible for retrofit } \\
\text { applications }\end{array}$ & [38] [39] \\
\hline $\begin{array}{l}\text { Open loop } \\
\text { scrubber }\end{array}$ & $\begin{array}{l}\text { High Sulphur dioxide } \\
\left(\mathrm{SO}_{\mathrm{x}}\right) \text { removal efficiency } \\
\text { (up to } 98 \%) \\
\text { Offers the possibility to } \\
\text { use the cheaper bunker }\end{array}$ & $\begin{array}{ll}\text { - } & \text { Subject to corrosion } \\
\text { (seawater) }\end{array}$ & $\begin{array}{l}{[34][35]} \\
{[36][37]}\end{array}$ \\
\hline $\begin{array}{l}\text { Closed loop } \\
\text { scrubber }\end{array}$ & $\begin{array}{l}\text { fuel than medium or } \\
\text { low Sulphur fuel } \\
\text { - Reduce the PM by } 60 \%\end{array}$ & $\begin{array}{l}\text { - Requires storage space to } \\
\text { hold waste water and } \\
\text { hazardous chemical } \\
\text { solutions } \\
\text { - High consumption of } \\
\text { fresh water } \\
\text { - Crews must be trained to } \\
\text { manipulate waste water } \\
\text { and chemical solutions }\end{array}$ & $\begin{array}{l}{[34][35]} \\
{[36][37]}\end{array}$ \\
\hline $\begin{array}{l}\text { Ecospec } \\
\text { CSNOx }\end{array}$ & 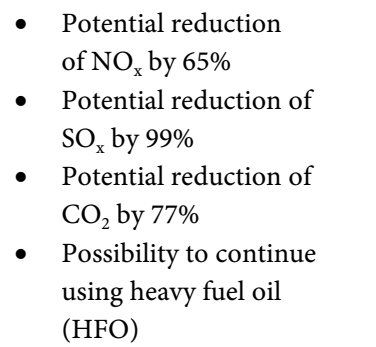 & $\begin{array}{l}\text { - } \text { High investment cost } \\
\text { - } \text { Requires additional } \\
\text { generator power } \\
\text { Machinery and stacking } \\
\text { arrangements: for } \\
\text { retrofits, fitting this } \\
\text { equipment into existing } \\
\text { spaces will be a major } \\
\text { challenge }\end{array}$ & $\begin{array}{l}{[34][35]} \\
{[36][37]}\end{array}$ \\
\hline
\end{tabular}

Table 4. Technical characteristics for category 3 marine diesel engines for medium and low speed categories.

\begin{tabular}{ccccccc}
\hline Speed & Medium & Medium & Medium & Low & Low & Low \\
\hline Engine power $(\mathrm{kW})$ & 4500 & 9500 & 18,000 & 8500 & 15,000 & 48,000 \\
Cylinders & 9 & 12 & 16 & 6 & 8 & 12 \\
Liter/cylinder & 35 & 65 & 95 & 380 & 650 & 1400 \\
Engine speed (rpm) & 650 & 550 & 500 & 130 & 110 & 100 \\
\hline
\end{tabular}

the considered technology. Component manufacturer costs have been estimated from different sources, including information from marine diesel engine manu- 
facturers and previous work done by the author of Costs of Emission Reduction Technologies for Category 3 Marine Engines. Costs include hardware and fixed costs.

Fixed costs reflect the need for manufacturers to focus on adapting emission controls to specific applications for marine diesel engines, with significant engine calibration required to optimize these controls over a wide range of ship types and operating conditions. Fixed cost/engine was supplied by EPA.

Hardware charges furnished by a supplier other than engine manufacturer are subject to a $29 \%$ mark up, which is an average supplier mark up of new engine sales technologies [40] [41].

However, for the estimated emission reduction, a load factor of 0.768 is calculated at $11 \%$ of the baseline emissions for 6000 hours per year over 5 years. Baseline $\mathrm{NO}_{\mathrm{x}}$ emission rates for medium speed motors are $14 \mathrm{~g} / \mathrm{kWh}$ and $18.1 \mathrm{~g} / \mathrm{kWh}$ for slow speed motors. This calculates emission reductions in metric tons as follows:

- Slow speed engines: $18.1 \mathrm{~g} / \mathrm{kWh} \times$ Power $(\mathrm{kWh}) \times 0.768 \times 6000$ hours $/ \mathrm{yr} \times 5$ years $/ 1,000,000 \mathrm{~g}$ metric tonne $\times 11 \%$

- Medium speed engines: $14 \mathrm{~g} / \mathrm{kWh} \times$ Power $(\mathrm{kWh}) \times 0.768 \times 6000$ hours $/ \mathrm{yr} \times$ 5 years/1,000,000g metric tonne $\times 11 \%$

\subsubsection{Emulsified Fue}

Costs for emulsified fuel include water storage tank costs, heat exchanger, ultrasonic homogenizer, distilled water and various pumps and pipes. These are detailed in Table 5. It is supposed that the water tank is made of cold rolled steel

Table 5. Cost of emission reduction technologies using emulsified fuel.

\begin{tabular}{ccccccc}
\hline Speed & Medium & Medium & Medium & Low & Low & Low \\
\hline Engine power $(\mathrm{kW})$ & 4500 & 9500 & 18,000 & 8500 & 15,000 & 48,000 \\
Component Cost & & & & & & \\
Water Tank & $\$ 1132$ & $\$ 1767$ & $\$ 2610$ & $\$ 1611$ & $\$ 2240$ & $\$ 4386$ \\
Ultrasonic Homogenizer & $\$ 37,500$ & $\$ 56,000$ & $\$ 75,000$ & $\$ 56,000$ & $\$ 75,000$ & $\$ 112,200$ \\
Heat Exchanger & $\$ 9400$ & $\$ 11,700$ & $\$ 14,000$ & $\$ 11,700$ & $\$ 14,000$ & $\$ 16,400$ \\
Pump/Piping & $\$ 4700$ & $\$ 5600$ & $\$ 6600$ & $\$ 5600$ & $\$ 6600$ & $\$ 7500$ \\
Total Component Cost & $\$ 52,732$ & $\$ 75,067$ & $\$ 98,210$ & $\$ 74,911$ & $\$ 97,840$ & $\$ 140,486$ \\
Assembly Labor (hr) & 240 & 320 & 400 & 320 & 400 & 480 \\
Cost (\$23.85/hr) & $\$ 5723$ & $\$ 7631$ & $\$ 9538$ & $\$ 7631$ & $\$ 9538$ & $\$ 11,446$ \\
Overhead@40\% & $\$ 2289$ & $\$ 3052$ & $\$ 3815$ & $\$ 3052$ & $\$ 3815$ & $\$ 4578$ \\
Total Assembly Cost & 8012 & 10,683 & 13,354 & 10,683 & $\$ 13,354$ & $\$ 16,025$ \\
Total Variable Cost & $\$ 60,744$ & $\$ 85,750$ & $\$ 111,564$ & $\$ 85,594$ & $\$ 111,194$ & $\$ 156,511$ \\
Markup@29\% & $\$ 17,616$ & $\$ 24,867$ & $\$ 32,354$ & $\$ 24,822$ & $\$ 32,246$ & $\$ 45,388$ \\
Total Hardware & $\$ 78,361$ & $\$ 110,617$ & $\$ 143,918$ & $\$ 110,417$ & $\$ 143,441$ & $\$ 201,899$ \\
Fixed Cost/Engine & $\$ 8103$ & $\$ 8103$ & $\$ 8103$ & $\$ 8103$ & $\$ 8103$ & $\$ 8103$ \\
Total Costs & $\$ 86,464$ & $\$ 118,720$ & $\$ 152,021$ & $\$ 118,520$ & $\$ 151,544$ & $\$ 210,001$ \\
Cost per kW & $\$ 19.2$ & $\$ 12.5$ & $\$ 8.4$ & $\$ 13.9$ & $\$ 10.1$ & $\$ 4.4$ \\
\hline
\end{tabular}


$1 \mathrm{~mm}$ thick and estimates water storage during emission control area (ECA) operation for 250 hours of normal operation.

\subsubsection{Direct Water Injection (DWI)}

DWI contains charges for a low and high-pressure module, water storage tank, water injectors, flow fuses control unit and the related piping. Table 6 shows costs the detailed information.

\subsubsection{Selective Catalytic Reduction (SCR)}

Selective Catalytic Reduction charges include reactor, the urea tank, dosage pump, injectors, control system, a bypass valve, cleaning probe and the acoustic horn. Retooling charges are for redesign of the exhaust system to entertain the SCR system. Table 7 shows costs the detailed information.

\subsubsection{Exhaust Gas Recirculation (EGR)}

EGR charges contain a sludge tank, supply pump, piping, waste pump, a recirculation pump, an EGR Valve, separator, a scrubber system and control system.

Table 6. Cost of emission reduction technologies using DWI.

\begin{tabular}{|c|c|c|c|c|c|c|}
\hline Speed & Medium & Medium & Medium & Low & Low & Low \\
\hline Engine Power (kW) & 4500 & 9500 & 18,000 & 8500 & 15,000 & 48,000 \\
\hline \multicolumn{7}{|l|}{ Component Cost } \\
\hline Water Tank & $\$ 1132$ & $\$ 1767$ & $\$ 2610$ & $\$ 1611$ & $\$ 2240$ & $\$ 4386$ \\
\hline Low Pressure Module & $\$ 4700$ & $\$ 7000$ & $\$ 9500$ & $\$ 9500$ & $\$ 19,000$ & $\$ 3800$ \\
\hline High Pressure Module & $\$ 9500$ & $\$ 14,000$ & $\$ 19,000$ & $\$ 19,000$ & $\$ 38,000$ & $\$ 75,000$ \\
\hline Piping & $\$ 5600$ & $\$ 7500$ & $\$ 9500$ & $\$ 9500$ & $\$ 14,000$ & $\$ 19,000$ \\
\hline Flow Fuses (each) & $\$ 1900$ & $\$ 1900$ & $\$ 1900$ & $\$ 1900$ & $\$ 1900$ & $\$ 1900$ \\
\hline Water Injectors (each) & $\$ 2400$ & $\$ 2400$ & $\$ 2400$ & $\$ 2400$ & $\$ 2400$ & $\$ 2400$ \\
\hline Number per Cylinder & 1 & 2 & 3 & 3 & 6 & 12 \\
\hline Control Unit/Wiring & $\$ 9500$ & $\$ 11,300$ & $\$ 13,000$ & $\$ 11,300$ & $\$ 13,000$ & $\$ 15,000$ \\
\hline Total Component Cost & $\$ 69,132$ & $\$ 144,767$ & $\$ 260,010$ & $\$ 128,311$ & $\$ 292,640$ & $\$ 736,386$ \\
\hline Assembly Labor (hr) & 500 & 750 & 1000 & 1000 & 1500 & 2000 \\
\hline Cost $(\$ 23.85 / \mathrm{hr})$ & $\$ 11,923$ & $\$ 17,885$ & $\$ 23,846$ & $\$ 23,846$ & $\$ 35,769$ & $\$ 47,692$ \\
\hline Overhead@40\% & $\$ 4769$ & $\$ 7154$ & $\$ 9538$ & $\$ 9538$ & $\$ 14,308$ & $\$ 19,077$ \\
\hline Total Assembly Cost & $\$ 16,692$ & $\$ 25,039$ & $\$ 33,384$ & $\$ 33,384$ & $\$ 50,077$ & $\$ 66,769$ \\
\hline Total Variable Cost & $\$ 85,825$ & $\$ 169,805$ & $\$ 293,395$ & $\$ 161,696$ & $\$ 342,717$ & $\$ 803,155$ \\
\hline Markup@29\% & $\$ 24,889$ & $\$ 49,244$ & $\$ 85,084$ & $\$ 46,892$ & $\$ 99,388$ & $\$ 232,915$ \\
\hline Total Hardware & $\$ 110,714$ & $\$ 219,049$ & $\$ 378,479$ & $\$ 208,588$ & $\$ 442,105$ & $\$ 1,036,070$ \\
\hline Fixed Cost/Engine & $\$ 74,891$ & $\$ 74,891$ & $\$ 74,891$ & $\$ 74,891$ & $\$ 74,891$ & $\$ 74,891$ \\
\hline Total Costs & $\$ 185,605$ & $\$ 293,940$ & $\$ 453,371$ & $\$ 283,479$ & $\$ 516,997$ & $\$ 1,110,960$ \\
\hline Cost per $\mathrm{kW}$ & $\$ 41.2$ & $\$ 30.9$ & $\$ 25.2$ & $\$ 33.4$ & $\$ 34.5$ & $\$ 23.1$ \\
\hline
\end{tabular}


Table 7. Cost of emission reduction technologies using SCR.

\begin{tabular}{|c|c|c|c|c|c|c|}
\hline Speed & Medium & Medium & Medium & Low & Low & Low \\
\hline Engine Power (kW) & 4500 & 9500 & 18,000 & 8500 & 15,000 & 48,000 \\
\hline \multicolumn{7}{|l|}{ Component Cost } \\
\hline Urea Tank & $\$ 1194$ & $\$ 1868$ & $\$ 2765$ & $\$ 1690$ & $\$ 2356$ & $\$ 4636$ \\
\hline Reactor & $\$ 200,000$ & $\$ 295,000$ & $\$ 400,000$ & $\$ 345,000$ & $\$ 560,000$ & $\$ 1,400,000$ \\
\hline Dosage Pump & $\$ 9500$ & $\$ 11,300$ & $\$ 13,000$ & $\$ 11,300$ & $\$ 13,000$ & $\$ 15,000$ \\
\hline Piping & $\$ 4700$ & $\$ 5600$ & $\$ 6600$ & $\$ 5600$ & $\$ 7500$ & $\$ 9500$ \\
\hline Injectors (each) & $\$ 2400$ & $\$ 2400$ & $\$ 2400$ & $\$ 2400$ & $\$ 2400$ & $\$ 2400$ \\
\hline Number of Injectors & 3 & 6 & 8 & 12 & 16 & 24 \\
\hline Bypass Valve & $\$ 4700$ & $\$ 5600$ & $\$ 6600$ & $\$ 5600$ & $\$ 6600$ & $\$ 7500$ \\
\hline Acoustic Horn & $\$ 9500$ & $\$ 11,300$ & $\$ 13,000$ & $\$ 11,700$ & $\$ 14,000$ & $\$ 16,400$ \\
\hline Control System & $\$ 14,000$ & $\$ 14000$ & $\$ 14,000$ & $\$ 19,000$ & $\$ 19,000$ & $\$ 19,000$ \\
\hline Cleaning Probe & $\$ 575$ & $\$ 575$ & $\$ 575$ & $\$ 900$ & $\$ 900$ & $\$ 900$ \\
\hline $\begin{array}{c}\text { Total Component } \\
\text { Cost }\end{array}$ & $\$ 251,369$ & $\$ 359,643$ & $\$ 475,740$ & $\$ 429,390$ & $\$ 661,556$ & $\$ 1,530,336$ \\
\hline Assembly Labor (hr) & 1000 & 1200 & 1500 & 1200 & 1600 & 2000 \\
\hline Cost $(\$ 23.85 / \mathrm{hr})$ & $\$ 23,846$ & $\$ 28,615$ & $\$ 35,769$ & $\$ 28,615$ & $\$ 38,154$ & $\$ 47,692$ \\
\hline Overhead@40\% & $\$ 9538$ & $\$ 11,446$ & $\$ 14,308$ & $\$ 11,446$ & $\$ 15,262$ & $\$ 19,077$ \\
\hline Total Assembly Cost & $\$ 33,384$ & $\$ 40,061$ & $\$ 50,077$ & $\$ 40,061$ & $\$ 53,416$ & $\$ 66,769$ \\
\hline Total Variable Cost & $\$ 284,753$ & $\$ 399,704$ & $\$ 525,816$ & $\$ 469,452$ & $\$ 714,971$ & $\$ 1,597,106$ \\
\hline Markup@29\% & $\$ 82,578$ & $\$ 115,914$ & $\$ 152,487$ & $\$ 136,141$ & $\$ 207,342$ & $\$ 463,161$ \\
\hline Total Hardware & $\$ 367,332$ & $\$ 515,618$ & $\$ 678,303$ & $\$ 605,593$ & $\$ 922,313$ & $\$ 2,060,266$ \\
\hline Fixed Cost/Engine & $\$ 22,699$ & $\$ 22,699$ & $\$ 22,699$ & $\$ 22,699$ & $\$ 22,699$ & $\$ 22,699$ \\
\hline Total Costs & $\$ 390,031$ & $\$ 538,317$ & $\$ 701,002$ & $\$ 628,292$ & $\$ 945,012$ & $\$ 2,082,965$ \\
\hline Cost per $\mathrm{kW}$ & $\$ 86.7$ & $\$ 56.7$ & $\$ 38.9$ & $\$ 73.9$ & $\$ 63$ & $\$ 43.4$ \\
\hline
\end{tabular}

Based on an average EGR rate of 20 percent, sludge is supposed to grow at 0.005 $\mathrm{g} / \mathrm{kWh}$ with a sludge density of $1300 \mathrm{~kg} / \mathrm{m}^{3}$. The sludge tank is intended to be made of $1 \mathrm{~mm}$ thick cold rolled steel. The tank will hold sludge from engine operation over 500 hours. Table 8 illustrates the cost of emission reduction technologies using the exhaust gas recirculation.

\subsubsection{Seawater Scrubber}

Scrubber charges contain the sludge tank, supply pump, a waste pump, a recirculation pump, an $\mathrm{SO}_{2}$ monitor, oil and water separator, the scrubber system and control system. Sludge tank acquires a sludge buildup rate of $0.25 \mathrm{~g} / \mathrm{kWh}$ and a sludge density of $1300 \mathrm{~kg} / \mathrm{m}^{3}$.

It is envisioned to be made of cold rolled steel $1 \mathrm{~mm}$ thick and will hold sludge generated from engine operation over 500 hours. Table 9 illustrates the cost of emission reduction technologies using the seawater scrubber. 
Table 8. Cost of emission reduction technologies using EGR.

\begin{tabular}{|c|c|c|c|c|c|c|}
\hline Speed & Medium & Medium & Medium & Low & Low & Low \\
\hline Engine Power (kW) & 4500 & 9500 & 18,000 & 8500 & 15,000 & 48,000 \\
\hline \multicolumn{7}{|l|}{ Component Cost } \\
\hline Sludge Tank & $\$ 268$ & $\$ 345$ & $\$ 435$ & $\$ 511$ & $\$ 635$ & $\$ 859$ \\
\hline Supply Pump & $\$ 1900$ & $\$ 2600$ & $\$ 3600$ & $\$ 2600$ & $\$ 4400$ & $\$ 7000$ \\
\hline Waste Pump & $\$ 1900$ & $\$ 2800$ & $\$ 3800$ & $\$ 2800$ & $\$ 4700$ & $\$ 7500$ \\
\hline Recirculation Pump & $\$ 1900$ & $\$ 2800$ & $\$ 3800$ & $\$ 2800$ & $\$ 4700$ & $\$ 7500$ \\
\hline Scrubber Unit & $\$ 23,500$ & $\$ 35,000$ & $\$ 56,000$ & $\$ 32,700$ & $\$ 56,000$ & $\$ 112,200$ \\
\hline EGR Valve & $\$ 7000$ & $\$ 9500$ & $\$ 11,700$ & $\$ 9500$ & $\$ 11,700$ & $\$ 14,000$ \\
\hline Separator & $\$ 1900$ & $\$ 2800$ & $\$ 3800$ & $\$ 2800$ & $\$ 3800$ & $\$ 4700$ \\
\hline Piping & $\$ 2800$ & $\$ 3800$ & $\$ 4700$ & $\$ 3700$ & $\$ 4700$ & $\$ 5600$ \\
\hline Control System & $\$ 4700$ & $\$ 4700$ & $\$ 4700$ & $\$ 4700$ & $\$ 4700$ & $\$ 4700$ \\
\hline Total Component Cost & $\$ 45,868$ & $\$ 64,345$ & $\$ 92,535$ & $\$ 62,111$ & $\$ 95,335$ & $\$ 164,059$ \\
\hline Assembly Labor (hr) & 200 & 300 & 400 & 300 & 400 & 500 \\
\hline Cost $(\$ 23.85 / \mathrm{hr})$ & $\$ 4769$ & $\$ 7154$ & $\$ 9538$ & $\$ 7154$ & $\$ 9538$ & $\$ 11,923$ \\
\hline Overhead@40\% & $\$ 1908$ & $\$ 2862$ & $\$ 3815$ & $\$ 2862$ & $\$ 3815$ & $\$ 4769$ \\
\hline Total Assembly Cost & $\$ 6677$ & $\$ 10,015$ & $\$ 13,354$ & $\$ 10,015$ & $\$ 13,354$ & $\$ 16,692$ \\
\hline Total Variable Cost & $\$ 52,545$ & $\$ 74,361$ & $\$ 105,888$ & $\$ 72,127$ & $\$ 108,689$ & $\$ 180,751$ \\
\hline Markup@29\% & $\$ 15,238$ & $\$ 21,565$ & $\$ 30,708$ & $\$ 20,917$ & $\$ 31,520$ & $\$ 52,418$ \\
\hline Total Hardware & $\$ 67,783$ & $\$ 95,925$ & $\$ 136,596$ & $\$ 93,044$ & $\$ 140,208$ & $\$ 233,169$ \\
\hline Fixed Cost/Engine & $\$ 17,889$ & $\$ 17,889$ & $\$ 17,889$ & $\$ 17,889$ & $\$ 17,889$ & $\$ 17,889$ \\
\hline Total Costs & $\$ 85,672$ & $\$ 113,814$ & $\$ 154,485$ & $\$ 110,932$ & $\$ 158,097$ & $\$ 251,058$ \\
\hline Cost per $\mathrm{kW}$ & $\$ 19$ & $\$ 12$ & $\$ 8.6$ & $\$ 13.1$ & $\$ 10.5$ & $\$ 5.2$ \\
\hline
\end{tabular}

\subsubsection{Fuel Switching}

In this section, hardware charges related to fuel switching are presented. We pretend that the ships have sufficient storage tank capacity for fuel switching and all the appropriate equipment to achieve fuel switching in an Emission Control Area (ECA). The Air Resources Board (ARB) evaluates that $78 \%$ of all ships fall into this category based on their survey. Table 10 shows the cost of emission reduction technologies using the fuel switching.

Economics impact for low and medium speed for category 3 marine diesel engines are shown in Figure 9 (for low speed marine engines) and in Figure 10 (for medium speed marine engines), where they are associated to $\mathrm{kW} /$ hour and $\mathrm{kg}$ fuel burned commonly for different engine grades and different emission reduction technology.

Based on the analysis and calculations, fuel switching technologies is the least 
Table 9. Cost of emission reduction technologies using seawater scrubber.

\begin{tabular}{|c|c|c|c|c|c|c|}
\hline Speed & Medium & Medium & Medium & Low & Low & Low \\
\hline Engine Power (kW) & 4500 & 9500 & 18,000 & 8500 & 15,000 & 48,000 \\
\hline \multicolumn{7}{|l|}{ Component Cost } \\
\hline Supply Pump & $\$ 9500$ & $\$ 14,000$ & $\$ 19,000$ & $\$ 14,000$ & $\$ 23,500$ & $\$ 37,500$ \\
\hline Sludge Tank & $\$ 350$ & $\$ 481$ & $\$ 641$ & $\$ 637$ & $\$ 818$ & $\$ 1256$ \\
\hline Piping & $\$ 4700$ & $\$ 5600$ & $\$ 6600$ & $\$ 5600$ & $\$ 7500$ & $\$ 9500$ \\
\hline Waste Pump & $\$ 9500$ & $\$ 11,300$ & $\$ 13,000$ & $\$ 11,300$ & $\$ 13,000$ & $\$ 15,000$ \\
\hline Recirculating Pump & $\$ 9500$ & $\$ 11,300$ & $\$ 13,000$ & $\$ 11,300$ & $\$ 13,000$ & $\$ 15,000$ \\
\hline Scrubber & $\$ 215,000$ & $\$ 355,000$ & $\$ 550,000$ & $\$ 340,000$ & $\$ 500,000$ & $\$ 1,125,000$ \\
\hline Separator & $\$ 7000$ & $\$ 8000$ & $\$ 9000$ & $\$ 8000$ & $\$ 9000$ & $\$ 10,000$ \\
\hline SO2 monitor & $\$ 9500$ & $\$ 9500$ & $\$ 9500$ & $\$ 9500$ & $\$ 9500$ & $\$ 9500$ \\
\hline Control System & $\$ 28,000$ & $\$ 28,000$ & $\$ 28,000$ & $\$ 28,000$ & $\$ 28,000$ & $\$ 28,000$ \\
\hline Total Component Cost & $\$ 293,050$ & $\$ 443,181$ & $\$ 648,741$ & $\$ 428,337$ & $\$ 604,318$ & $\$ 1,250,756$ \\
\hline Assembly Labor (hr) & 600 & 800 & 1000 & 1000 & 1500 & 2000 \\
\hline Cost $(\$ 23.85 / \mathrm{hr})$ & $\$ 14,308$ & $\$ 19,077$ & $\$ 23,846$ & $\$ 23,846$ & 35,769 & $\$ 47,692$ \\
\hline Overhead@40\% & $\$ 5723$ & $\$ 7631$ & $\$ 9538$ & $\$ 9538$ & $\$ 14,308$ & $\$ 19,077$ \\
\hline Total Assembly Cost & $\$ 20,031$ & $\$ 26,708$ & $\$ 33,385$ & $\$ 33,385$ & $\$ 50,077$ & $\$ 66,769$ \\
\hline Total Variable Cost & $\$ 313,081$ & $\$ 469,888$ & $\$ 682,126$ & $\$ 461,722$ & $\$ 654,395$ & $\$ 1,1317,525$ \\
\hline Markup@29\% & $\$ 90,794$ & $\$ 136,268$ & $\$ 197,817$ & $\$ 133,899$ & $\$ 189,774$ & $\$ 382,082$ \\
\hline Total Hardware & $\$ 403,875$ & $\$ 606,156$ & $\$ 879,943$ & $\$ 595,621$ & $\$ 844,169$ & $\$ 1,699,608$ \\
\hline Fixed Cost/Engine & $\$ 17,889$ & $\$ 17,889$ & $\$ 17,889$ & $\$ 17,889$ & $\$ 17,889$ & $\$ 17,889$ \\
\hline Total Costs & $\$ 421,763$ & $\$ 624,045$ & $\$ 897,831$ & $\$ 613,510$ & $\$ 862,058$ & $\$ 1,717,497$ \\
\hline Cost per kW & $\$ 93.7$ & $\$ 65.7$ & $\$ 49.9$ & $\$ 72.2$ & $\$ 57.5$ & $\$ 35.8$ \\
\hline
\end{tabular}

expensive among the different technologies presented in this review, while sea water scrubbers remain the most expensive technology to adopt.

It can also be seen that the prices vary proportionally depending on the power rate of the engine but in the case of the DWI technique, the cost of adaptation on a $15,000 \mathrm{~kW}$ (for low speed) is slightly higher than that of $8500 \mathrm{~kW}$ due to the number of hours required for assembly and installation, while it is also higher than that of $48,000 \mathrm{~kW}$ because the cost of $48,000 \mathrm{~kW}$ is twice that of $15,000 \mathrm{~kW}$ but 3, 2 times bigger in terms of power allowing a cost reduction cost by an average of $33 \%$. However, a combination of two or three technologies may prove attractive for shipowners to achieve significant emission reductions. In the future, the integration of multiple technologies will be the research direction of many vessels equipped with a marine diesel engine. 
Table 10. Cost of emission reduction technologies using the fuel switching.

\begin{tabular}{|c|c|c|c|c|c|c|}
\hline Speed & Medium & Medium & Medium & Low & Low & Low \\
\hline Engine Power $(\mathrm{kW})$ & 4500 & 9500 & 18,000 & 8500 & 15,000 & 48,000 \\
\hline \multicolumn{7}{|l|}{ Component Cost } \\
\hline Additional Tank & $\$ 3409$ & $\$ 5511$ & $\$ 8341$ & $\$ 4562$ & $\$ 6548$ & $\$ 13,733$ \\
\hline LFO Separator & $\$ 2800$ & $\$ 3300$ & $\$ 3800$ & $\$ 3800$ & $\$ 4200$ & $\$ 4700$ \\
\hline HFO/LFO Blending Unit & $\$ 4200$ & $\$ 4700$ & $\$ 5600$ & $\$ 4700$ & $\$ 5600$ & $\$ 6600$ \\
\hline 3-Way Valve & $\$ 950$ & $\$ 1400$ & $\$ 1900$ & $\$ 1400$ & $\$ 1900$ & $\$ 2800$ \\
\hline LFO Cooler & $\$ 2400$ & $\$ 2800$ & $\$ 3300$ & $\$ 2800$ & $\$ 3800$ & $\$ 4700$ \\
\hline Filters & $\$ 950$ & $\$ 950$ & $\$ 950$ & $\$ 950$ & $\$ 950$ & $\$ 950$ \\
\hline Viscosity Meter & $\$ 1400$ & $\$ 1400$ & $\$ 1400$ & $\$ 1400$ & $\$ 1400$ & $\$ 1400$ \\
\hline Piping/Pumps & $\$ 2000$ & $\$ 2000$ & $\$ 2000$ & $\$ 2000$ & $\$ 2000$ & $\$ 2000$ \\
\hline Total Component Cost & $\$ 8012$ & $\$ 10,683$ & $\$ 16,025$ & $\$ 10,683$ & $\$ 16,025$ & $\$ 20,031$ \\
\hline Assembly Labor (hr) & 240 & 320 & 480 & 320 & 480 & 600 \\
\hline Cost $(\$ 23.85 / \mathrm{hr})$ & $\$ 5723$ & $\$ 7631$ & $\$ 11,446$ & $\$ 7631$ & $\$ 11,446$ & $\$ 14,308$ \\
\hline Overhead@40\% & $\$ 2289$ & $\$ 3052$ & $\$ 4578$ & $\$ 3052$ & $\$ 4578$ & $\$ 5723$ \\
\hline Total Assembly Cost & $\$ 8012$ & $\$ 10,683$ & $\$ 16,025$ & $\$ 10,683$ & $\$ 16,025$ & $\$ 20,031$ \\
\hline Total Variable Cost & $\$ 26,121$ & $\$ 32,744$ & $\$ 43,316$ & $\$ 32,295$ & $\$ 42,423$ & $\$ 56,914$ \\
\hline Markup@29\% & $\$ 7575$ & $\$ 9496$ & $\$ 12,562$ & $\$ 9366$ & $\$ 12,303$ & $\$ 16,505$ \\
\hline Total Hardware & $\$ 33,696$ & $\$ 42,240$ & $\$ 55,877$ & $\$ 41,661$ & $\$ 54,725$ & $\$ 73,419$ \\
\hline Fixed Cost/Engine & $\$ 1233$ & $\$ 1233$ & $\$ 1233$ & $\$ 1233$ & $\$ 1233$ & $\$ 1233$ \\
\hline Total Costs & $\$ 34,929$ & $\$ 43,473$ & $\$ 57,110$ & $\$ 42,894$ & $\$ 55,958$ & $\$ 74,652$ \\
\hline Cost per kW & $\$ 7.8$ & $\$ 4.6$ & $\$ 3.2$ & $\$ 5.0$ & $\$ 3.7$ & $\$ 1.6$ \\
\hline
\end{tabular}

\section{Conclusions}

Ship emissions are one of the major issues affecting those interested in the maritime domain, as they have a negative impact on the marine environment. In this paper, a review and economic impact analysis of different emission reduction techniques for marine diesel engines have been presented.

According to Figure 9 and Figure 10, using fuel switching technique as pre-treatment technology onboard ships appeared the best methods at long-term from the point of view of cost, while sea water scrubbers as post-treatment technology will be costly and add more ship operating cost. On the other hand, pre-treatment technologies such as the use of Methanol or LNG as marine fuel compared to HFO, reduce dependency on conventional fuels and have environmental benefits through an average reduction. However, due to the fact that both gases have significant differences in terms of characteristics and properties than 


\section{Economic Impact For Medium Speed \\ For Category 3 Marine Diesel Engines}

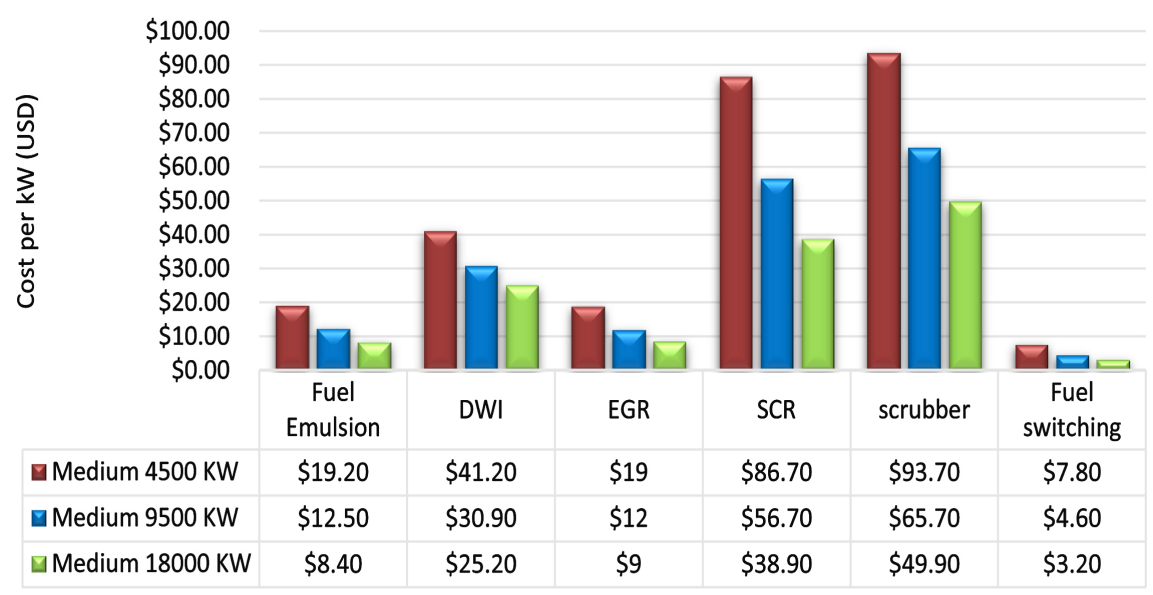

Figure 9. Cost per kW (USD) for a medium speed for category 3 marine diesel engines.

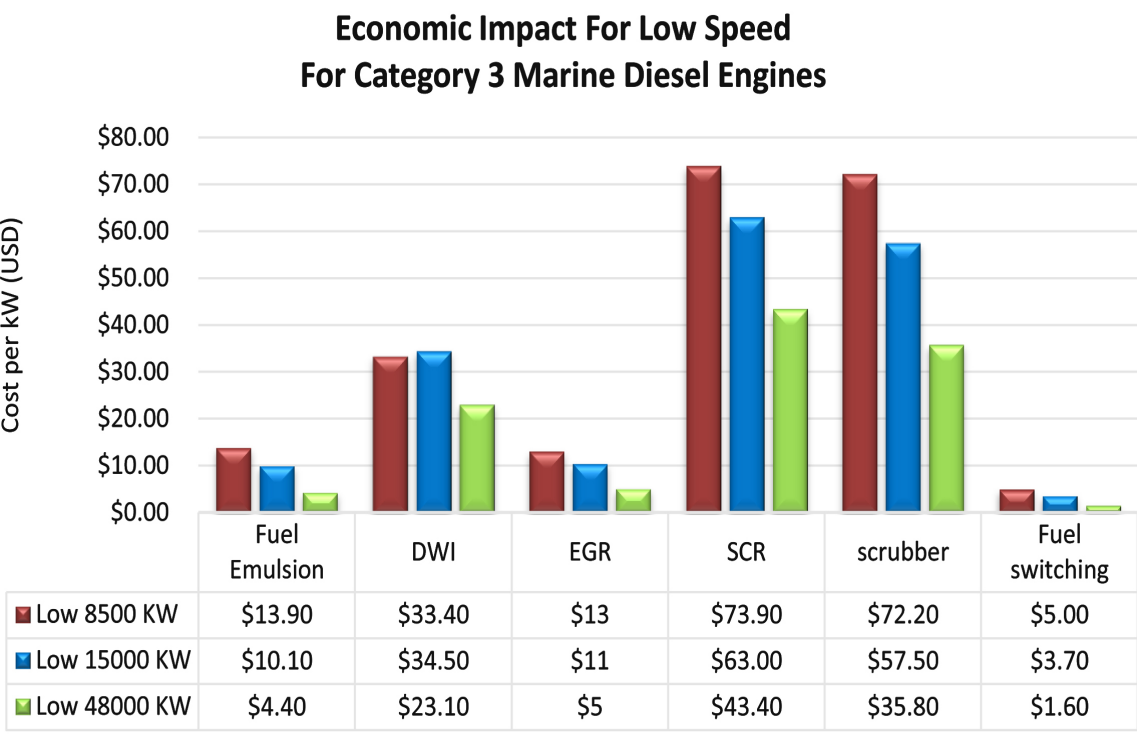

Figure 10. Cost per kW (USD) for a low speed for category 3 marine diesel engines.

conventional marine fuels, they are subject to storage challenges and require high capital cost in order to integrate them aboard ships in service. Appropriate integration for these gases as marine fuel is suitable for future ships to come.

It also was shown that internal-treatment technologies such as EGR and DWI in order to reduce oxides of nitrogen are mostly mature and are present in new marine DEs. The most advanced technology that can come in force with internal-treatment is the post-treatment, principally using SCR. However, due to the high price of reactor and the storage of urea in proportion to the fuel carried, SCR becomes the second most expensive technique after the scrubber.

Finally, the combination of two or three technologies is possible and can offer new solutions with high efficiency from the viewpoint of environmental and economic issues. 


\section{Conflicts of Interest}

The authors declare no conflict of interest regarding the publication of this paper.

\section{References}

[1] Seddiek, S. and Elgohary, M. (2014) Eco-Friendly Selection of Ship Emissions Reduction Strategies with Emphasis on Sox and NOx Emissions. International Journal of Naval Architecture and Ocean Engineering, 6, 737-748. https://doi.org/10.2478/IJNAOE-2013-0209

[2] Lin, B and Lin, C.Y. (2006) Compliance with International Emission Regulations: Reducing the Air Pollution from Merchant Vessels. Marine Policy, 30, 220-225. https://doi.org/10.1016/j.marpol.2005.01.005

[3] International Maritime Organization (2015) Third IMO GHG Study 2014. Report, International Maritime Organization, London.

[4] Hermann, R.R. (2017) Drivers for Environmental Technologies Selection in the Shipping Industry: A Case Study of the North European Sulphur Emission Control Area. International Journal of Environmental Technology and Management, 20, 139-162. https://doi.org/10.1504/IJETM.2017.10010687

[5] Ueno, C. (2010) Understanding Tier 4 Interim and Tier 4 Final. MTU onsite Energy. https://www.mtu-online.com/uploads/tx_templavoila/WhitePaper_Tier4i_and_Tier 4_02.pdf

[6] Kristensen, H.O. (2012) Energy Demand and Exhaust Gas Emissions of Marine Engines. Clean Shipping Currents, 1, 18-26.

[7] Lamas, M.I. and Rodriguez, C.G. (2012) Emissions from Marine Engines and NOx Reduction Methods. Journal of Maritime Research, 9, 77-81.

[8] Woodyard, D. (2009) Pounder's Marine Diesel Engines and Gas Turbines. Ninth Edition, Elsevier, Oxford, 61-87.

[9] Man Diesel Turbo (2009) Exhaust Gas Emission Control Today and Tomorrow. https://marine.mandieselturbo.com/docs/librariesprovider6/technical-papers/exhau st-gas-emission-control-today-and-tomorrow.pdf?sfvrsn $=22$

[10] Cariou, P. (2011) Is Slow Steaming a Sustainable Means of Reducing $\mathrm{CO}_{2}$ Emissions from Container Shipping? Transportation Research Part D: Transport and Environment, 16, 260-264. https://doi.org/10.1016/j.trd.2010.12.005

[11] Kuiken, K. (2017) Diesel Engines: For Ship Propulsion and Power Plants from 0 to 100,000Kw. In: Regulations for Propulsion Engines, Classification, Repair and Damage, 3rd Edition, Onnen Target Global Energy Training, Netherlands, 398-424.

[12] Kristensen, H.O. (2015) Energy Demand and Exhaust Gas Emissions of Marine Engines. Mitigating and Reversing the Side-Effects of Environmental Legislation on RO-RO Shipping in Northern Europe. Report, Technical University of Denmark, Denmark.

[13] Rudzki, A and Carran, A. (2014) Assessment of Current and Future Air Pollutant Emission Reduction Technologies for Marine Diesel Engines. Report, Defense Research and Development Canada, Atlantic Research Centre, Victoria, Canada. https://apps.dtic.mil/dtic/tr/fulltext/u2/a603708.pdf

[14] Issa, M., Ibrahim, H., Lepage, R. and Ilinca, A. (2019) A Review and Comparison on Recent Optimization Methodologies for Diesel Engines and Diesel Power Genera- 
tors. Journal of Power and Energy Engineering, 7, 31-56.

https://doi.org/10.4236/jpee.2019.76003

[15] Elgohary, M, Seddiek, S. and Salem, A.M. (2015) Overview of Alternative Fuels with Emphasis on the Potential of Liquified Natural Gas as Future Marine Fuel. Proceedings of the Institution of Mechanical Engineers, Part M: Journal of Engineering for the Maritime Environment, 229, 365-375. https://doi.org/10.1177/1475090214522778

[16] Sastre, B.L. (2017) Implementation of LNG as Marine Fuel in Current Vessels: Perspectives and Improvements on Their Environmental Efficiency. Master Thesis, Universitat Politècnica de Catalunya, Spain.

[17] Nilsen, O.V. (2018) LNG Regulatory Update "Best Fuel of the Future". Internationalisation Conference on LNG Project \& the Baltic Sea Region LNG Cluster, Bergen, Norway, 10-12 April 2018.

http://www.golng.eu/files/Main/20180417/2.\%20Ole\%20Vidar\%20Nilsen\%20-\%20 DNV\%20GL.pdf

[18] Levander, O. (2011) Dual Fuel Engines Latest Developments. Technical Report, Wärtsilä, Concept Design, Hamburg.

https://www.stg-online.org/veranstaltungen/Ship_Efficiency_2017.html

[19] Zhou, S., Liu, Y. and Zhou, J.X. (2014) A Study on Exhaust Gas Emission Control Technology of Marine Diesel Engine. Advanced Materials Research, 864, 1804-1809. https://doi.org/10.4028/www.scientific.net/AMR.864-867.1804

[20] Wärtsilä Engines (2017) Wärtsilä 20DF Four-Stroke Dual-Fuel Engine. Report, Wärtsilä, Helsinki, Finland.

https://cdn.wartsila.com/docs/default-source/product-files/engines/df-engine/broch ure-o-e-w20df.pdf?utm_source=engines\&utm_medium $=$ dfengines\&utm_term $=w 20$ df\&utm_content=brochure\&utm_campaign=msleadscoring

[21] Zheng, Z., Yao, M.F., Zhang, B. and Chen, Z. (2005) Experimental Study on Performance and Emissions Characteristics of HCCI Operation for DME/Methanol Dual Fuel. Transactions of CSICE, 23, 32-36.

[22] Martz, J. (2011) Focusing on Dual-Fuel Engine Benefits. Consulting-Specifying Engineer Magazine and Newsletters.

https://www.csemag.com/articles/focusing-on-dual-fuel-engine-benefits

[23] Wärtsilä Corporation (2006) The Engine of Industry. Wärtsilä Annual Report, Helsinki, Finland.

https://www.wartsila.com/docs/default-source/investors/financial-materials/annualreports/annual-report-2006.pdf?sfvrsn=b1b31c45_2

[24] Wang, Y., Lin, L., Roskilly, A., Zeng, S., et al. (2007) An Analytic Study of Applying Miller Cycle to Reduce NOx Emission from Petrol Engine. Applied Thermal Engineering, 27, 1779-1789. https://doi.org/10.1016/j.applthermaleng.2007.01.013

[25] Kovacs, D. and Eilts, P. (2015) Potentials of the Miller Cycle on HD Diesel Engines Regarding Performance Increase and Reduction of Emissions. SAE International, No. 2015-24-2440. https://doi.org/10.4271/2015-24-2440

[26] Goldsworthy, L. (2002) Design of Ship Engines for Reduced Emission of Oxides Nitrogen. Engineering a Sustainable Future Conference Proceeding, Australian Maritime College, Launceston.

[27] Geist, M. (1998) Sulzer RTA-8T Engines: Compact Two Stroke for Tankers and Bulk Carriers. Report, Wärtsilä NSD Switzerland Ltd., Winterthur.

[28] Kech, J., Hegner, R. and Mannle, T. (2014) Turbocharging: Key Technology for High-Performance Engines. MTU Engine Technology White Paper. 
[29] Agarwal, D., Singh, S.K. and Agarwal, A.K. (2011) Effect of Exhaust Gas Recirculation (EGR) on Performance, Emissions, Deposits and Durability of a Constant Speed Compression Ignition Engine. Applied Energy, 88, 2900-2907. https://doi.org/10.1016/j.apenergy.2011.01.066

[30] Andersson, K., et al. (2016) Shipping and the Environment. In: Andersson, K., Brynolf, S., Lindgren, J. and Wilewska-Bien, M., Eds., Shipping and the Environment, Springer-Verlag, Berlin, Heidelberg. https://doi.org/10.1007/978-3-662-49045-7_1

[31] Ibrahim, S. (2016) Process Evaluation of a Sox and NOx Exhaust Gas Cleaning Concept for Marine Application. Master of Science Thesis, Chalmers University of Technology, Sweden.

[32] Ecospec Global Technology Pte Limited (2015) CSNOx-Ultra Low Frequency, Singapore. http://www.ecospec.com/marine-csnox

[33] International Maritime Organization (2018) Marine Environment Protection Committee on Its Fifty-Eighth Session. Marine Environment Protection Committee. MEPC 58/23, United Kingdom. http://ec.europa.eu/environment/waste/ships/pdf/report_mepc58.pdf

[34] Reynolds, K.J., Caughlan, S.A. and Strong, R.S. (2011) Exhaust Gas Cleaning Systems-Selection Guide. Report, U.S. Department of Transportation. File No. 10047.01.

[35] Entec UK Limited (2005) Service Contract on Ship Emissions. Assignment, Abatement and Market Based Instruments. Final Report, European Commission Directorate General Environment.

[36] Issa, M., Beaulac, P., Ibrahim, H. and Ilinca, A. (2019) Marinization of a Two-Stage Mixed Structured Packing Scrubber for Sox Abatement and $\mathrm{CO}_{2}$ Capture. International Journal of Advanced Research, 7, 73-82. https://doi.org/10.21474/IJAR01/8793

[37] Chew, H.H. (2012) U.S. Patent No. 8,241,597. U.S. Patent and Trademark Office, Washington DC.

[38] Cimino, S., Lisi, L. and Tortorelli, M. (2016) Low Temperature SCR on Supported $\mathrm{MnO}_{\mathrm{x}}$ Catalysts for Marine Exhaust Gas Cleaning: Effect of $\mathrm{KCl}$ Poisoning. Chemical Engineering Journal, 283, 223-230. https://doi.org/10.1016/j.cej.2015.07.033

[39] Ballinger, T., Cox, J., Konduru, M., De, D., Manning, W. and Andersen, P. (2009) Evaluation of SCR Catalyst Technology on Diesel Particulate Filters. SAE International Journal of Fuels and Lubricants, 2, 369-374.

https://www.jstor.org/stable/26273395 https://doi.org/10.4271/2009-01-0910

[40] Jack Faucett Associates (1985) Update of EPA's Motor vehicle Emission Control Equipment Retail Price Equivalent. Calculation Formula, Final Report.

[41] United States Environmental Protection Agency (2009) Costs of Emission Reduction Technologies for Category 3 Marine Engines. Final Report, Assessment and Standards Division Office of Transportation and Air Quality. 